\title{
Hematopoietic System
}

National Cancer Institute

\section{Source}

National Cancer Institute. Hematopoietic System. NCI Thesaurus. Code C12909.

The bodily system of org ans and tissues, primarily the bone marrow, spleen, tonsils, and lymph nodes, involved in the production of blood. 